\title{
8 Approaches to transformation and development
}

\author{
The case of the Redeemed Christian \\ Church of God, Nigeria
}

\author{
Babatunde A. Adedibu
}

\section{Introduction}

The proliferation of Pentecostal Churches across sub-Saharan Africa is described by Gifford $(2016,16)$ as 'perhaps the most salient social force in sub-Saharan Africa'. The changes within the Christian landscape are not only peculiar to Nigeria, but these churches have defied the forces of territorialisation and are perhaps one of the non-commodity exports from the African continent to North America, Europe and Asia. Indeed, African Pentecostalism is now globalised. Interestingly, the growth of Pentecostal Churches in Africa is taking place at a time when researchers are increasingly interested in the nexus between development and religion (Adedibu 2018, 1-9; Adogame 2016, 1-11; Bompani 2012, 307-330; Deneulin and Rakodi 2010, 45-46; Probasco 2016, 233-249; Schnable 2016, 216-232). While acknowledging the complex nature of those two mysterious phenomena as observed by Adogame $(2016,2)$, it behoves us to note that they are linked to one another. Religious institutions like the Redeemed Christian Church of God (RCCG) are one of several examples of African Pentecostalism that are thriving and actively involved in the personal transformation of their adherents and development of the Nigerian state. Until recently, social scientists have not considered religion as a factor to reckon with in modern development theories. According to Adogame (2013), development was primarily conceived as an economic growth model. However, Adogame $(2016,2)$ argues that 'it is expedient that scholars explore religion as development and development as religion; just as further problematising the concept of "development as religious discourse" and "religion as development discourse"'. This highlights the complexity of the nexus between religion and development. Adogame's perspective highlighted above further led to his advocacy of the concept of development from below which does not

foist definitions and concepts on religious peoples and institutions, it is imperative on scholars and development actors and agencies to auscultate how and to what extent religious actors and their institutions may define, critique, conceptualise and theologise development, human progress and 
flourishing not only through abstract, metaphysical and canonical expressions, but also in concrete, prosaic, lived experiences.

Development paves way for maximisation of human dignity, fulfilment, equity and quality of life through the appropriation of right choices devoid of social, economic and political discountinuties (Ellis and Ter Haar 2006, 351-367). Tarimo $(2005,12)$ affirms this perspective as he posits that:

Development must be (ought to be) understood regarding a liberation process in which the whole person and the entire community are involved. Such a basic definition calls us to approach development as an ongoing transformation of society which not only ensures that everybody has the necessities of life, but that the decision-making process in society is genuinely participatory. Development then, is a multidimensional revolution, economic, social and cultural, to release and mobilize the energies and potentialities of the people.

The above asserts that development is not synonymous only with the economic growth model. It is quite intriguing that in over 27 years of extensive research and publications by the United Nations Development Programme (UNDP) of Human Development Reports (HDRs), religion is yet to be considered a major factor in development. In the $2015 \mathrm{HDR}$, it was stated in the foreword by Clark (2015, iii) that:

Twenty-five years ago the first Human Development Report in 1990 began with a simple notion: that development is about enlarging people's choices - focusing broadly on the richness of human lives rather than narrowly on the richness of economies.

Applauding the founding objective of this annual publication by the UNDP and the production of over 700 reports which claim to give more opportunities for people to make more choices, has repeatedly failed to consider religion as a correlate of human development (Commission for Africa 2005, 127-129; Ellis and Ter Haar 2004, 352; Marshall and Keough 2004). As understandable as it might seem with religious fanaticism and terrorism on the upsurge, particularly in the West and Africa, many do not have a firm grasp of what religion entails. As such, the importance of religion in human development has been grossly understated. Interestingly, some international agencies are appropriating the role of religion in development such as the Department for International Development, World Bank and International Monetary Fund (Belshaw et al. 2001, 7-16). In the year 2000, the World Bank and Anglican provinces in Africa jointly organised a conference on the theme of religion and development, seeking ways to partner with the churches as agents of development in their contexts. Nevertheless, sceptics of religion claim it is synonymous with poverty, 


\section{8}

as observed by Crabtree (2010). A typical argument to support the previous assertion is the fact that most nations where religion is thriving are either classified as underdeveloped or Third World countries due to low median per-capita income while secularised countries in the West where religion is domiciled in the private space have higher average per-capita income (Crabtree 2010). However, religion plays a functional role in development in sub-Saharan African and among Africans in diaspora in addressing their existential challenges and family life.

Given these emerging trends within development circles, Offutt et al. (2016, 207-215) have called on sociologists to explore the link between religion and development due to the changing pattern of funding challenges and the competitiveness among faith-based organisations and secular groups. Adogame $(2016,12)$ opines that most of the previous scholarships failed to consider the impact of colonialism and imperialism on the development of the African continent, leading to labels such as underdeveloped or developing nations or at best Third World economies. He further argues that despite the end of colonialism and imperialism the continent still suffers 'from the deleterious effects of Western Colonialism and neo-colonialism'. Adogame $(2016,4)$ berates the hegemony of the West for the economic subjugation, tyrannical as well as a bigoted disposition on the imposition of western knowledge that

collided with indigenous knowledge systems in a spate of bricolage of knowledge. The knowledge funnelled through the colonial process took centre stage, assuming a dominant epistemology that marginalized and almost silenced alternative worldviews and conceptualizations of the universe.

Despite the paucity of Adogame's assertion, he fails to acknowledge the postcolonial era of the financial and moral corruption of African leaders, and the continued exploitation of their states by being tied to the aprons of Swiss banks as the safe financial haven of their loot. However, Adogame $(2016,12)$ has berated the impact of the massive imperialistic notions by missionaries and colonialists as it heralded an era of superimposition of western ideals espoused through the lens of enlightenment that normalises a form of 'otherliness and binaries of differences adopted as tradition versus modernity, modernity, primitive versus civilised, superiority versus inferiority complex, developed versus undeveloped'. In light of the above assertions, Adogame $(2016,2)$ calls for a reappraisal of the western definition of development as he claims 'we need to re-interrogate and reinterpret the definitions of development from above against the backdrop of colonialism and the economics of unequal exchange'. Ellis and Ter Haar $(2006,362)$ have worked out a call for a paradigm shift on the definition of development through the religious lens with respect to developing countries:

if poor countries are to develop, it is not so much new policy instruments that are needed, but rather a new vision of what development means, and 
how it should be implemented. People's full range of resources should provide the foundation for any development strategy.

Ter Haar and Ellis further noted that a holistic perspective of development should include people's religious or spiritual resources, fiscal or material resources in the pursuit of tranquillity and safety, the value of governance, finance, health and education which are pivotal to development. The historical credibility of religious institutions and communal life in sub-Saharan Africa validates these institutions to be major development actors in their contexts (Frost et al. 2018; Öhlmann et al. 2016).

However, in Paul Gifford's (2016) recent volume Christianity, Development, and Modernity in Africa Gifford presents the role of African Pentecostalism in development in a different perspective. ${ }^{1}$ Gifford was apologetic in the opening pages of the book that criticism is expected as a matter of misconception or broad generalisations. Adedibu (2017, 94) noted that Gifford 'observed significance about Africa, Christian denominations, colonial emergence in Africa and the predatory disposition in the division of Africa' by the colonialists. However, from the front flap of the book, Adedibu (2017, 94) observed that:

Gifford set forth his views on observable theological and religious idiosyncrasies between African Christianity and historic denominations. The author describes the enchanted Christianity [and copiously] associates [it] with African Christianity and [describes] the disenchanted nature of historic denominations on human development.

Furthermore, Adedibu (2017, 94) identified Gifford's polemics on enchanted Christianity as he alluded to 'enchanted imagination, prosperity Gospel, and emphasis on the pastor's "anointing"', as defining characteristics of African Pentecostalism. Gifford's assertion is a misrepresentation of the hallmarks of African Pentecostalism.

Moreover, Gifford's perspective lacks contextual realities of the lived experiences of Africans negating the multifaceted nature of African Christianity and is trapped in broad oversimplifications of his assertion. Although it is expedient to appraise the role of Christianity and religion in sustainable development of Africa as posited by Gifford but to discountenance the contributions of religion to development in sub-Saharan Africa is wishful thinking. While Gifford applauds the role of religious organisations as development actors Adedibu $(2017,94)$ posits that

inadvertently [Gifford] seems trapped in essentialism as he [fails] to appreciate the heterogeneous and the uniqueness of African Christianities. Gifford's disposition implies the denial of the lived realities within the African context to address their existential realities as African Christianities, particularly [a] Pentecostal ethos which resonates in the traditional 
African [worldview] such as malevolent forces, curses, demons, witchcraft and exorcism.

The absurdity and flagrant denial of the spiritual realm raises further queries with respect to Gifford's claim of being well versed in the traditions of African Christianities. Although, Gifford's prescription of abandonment of enchanted Christianity which are major features of this Christian tradition, is a denial of the relevance of the theological and cultural sensibilities to Africans in Africa and diaspora as it addresses their existential realities. Adedibu (2017, 95) berated the isolationist orientation of Gifford's claim 'to condemn the Catholic Church, with its somewhat secularised development approach, of its insignificance for and ineffectiveness to offer an alternative solution to the enchanted religious needs of African Catholics is surprising'.

Furthermore, Gifford in this book failed to acknowledge that enchanted Christianity is a future of Charismatic Christianity which is fast becoming a major feature of Catholicism. The rabid claim to discountenance enchanted Christianity might suffice in a relativised society like the western world due to the effects of secularisation and enlightenment age but not in African Pentecostalism in Africa or the diaspora. Gifford's bloated perception of the contributions of the Catholic Church to the development of Africa is incomparable to other Christian traditions. The author's claim might have been correct during the colonial era in Africa (Adedibu 2017, 95), but in the last six decades, Pentecostal Churches have responded to some of the criticism of their tradition and have made an impressive impact on socioeconomic, political and educational initiatives in Africa and diaspora. It was quite evident that Gifford's treatise failed to critically examine the changing social, healthcare, economic and educational landscape of Africa which has the footprints of many Pentecostal Churches. Thus, African Christianity is redefining the concept of development from below and as such it is pertinent to interrogate the concept of development from below to demonstrate the contributions of religion using one of Africa's fastest-growing Pentecostal denominations as a case study. This work aims to contribute to the call for a paradigm shift by critically examining the role of RCCG in the transformation and development of Nigeria. My approach is at variance with normative economic growth models of development but within the remit of lived experiences of the Nigerian people. The import of such an approach is to defray scepticism about the contributions of religion to development from below as their 'narrative falls outside the radar of global, human development reports (HDRs) and indices' (Adogame 2016, 2). RCCG, Nigeria, is used as a case study.

\section{The RCCG's contributions to transformation and development of the Nigerian state}

RCCG is a Pentecostal Church that evolved in 1952 as an offshoot of an African Independent Church - Cherubim and Seraphim Church - started by the late Reverend Josiah Olufemi Akindayomi, who was unlettered, as a prayer 
band (Egbe Ogo-Oluwa (Glory of God)). Scholars in the mould of Adeboye $(2005,2007 \mathrm{~b})$ and Bolarinwa (2005) have published the call and ministry of the founder of the denomination in Africa and the diaspora. Akindayomi led RCCG until his demise on 2 November 1980 at the age of 72 . He was noted for his ascetic and Puritan disposition to wealth and profound prophetic ministry. The demise of Akindayomi heralded a new phase in the history of the denomination as Enoch Adejare Adeboye was chosen by 'divine fiat' as the next general superintendent of the denomination on 21 January 1981. Previous scholarship has researched extensively the transformation of RCCG to a world missionary player by Adeboye (Adogame 2007; Burgess et al. 2010; Ukah 2008). The current transnational status of RCCG is one of several examples of the globalisation of African Pentecostalism from Africa characterised by its idiosyncrasies. The appointment of Adeboye as RCCG General Overseer and his commitment to religious creativity through various programmes have led to a shift in the founding disposition of the church from world-rejecting notions to worldaccommodating ones. The repositioning initiatives as posited by Adedibu (2016) and doctrinal changes initiated by Adeboye have endeared the denomination to the upwardly mobile professionals across the entire social strata of Nigerian society, Africa and the diaspora.

\section{RCCG and civic engagement}

Various scholars, since the 1990s, have chronicled the dynamics of civil engagement of Pentecostalism in various countries in the global South and in the diaspora about the Pentecostal tradition as observed by Freeman (2012), Miller and Yamamori (2007), Gifford (1998) and others. Civic engagement, in the context of this study, is synonymous to the approaches and methodologies through which Pentecostal Churches influence and contribute to the development of their communities. Various approaches are utilised by faith-based organisations including the Pentecostal tradition based on the contextual analysis of the prevailing socioeconomic and cultural challenges of their communities. A Pentecostal denomination like RCCG has tremendous influence within its membership and as an agent of social transformation on wider civic culture. RCCG has succeeded not only regarding its missionising aspirations, but also contributing to the development of various communities where these churches are situated. The public visibility of RCCG is not limited to Nigeria, but also found in the diaspora.

The participatory model of the RCCG might be classified as the salt and light of its community. Various civic engagements of the denomination to ameliorate the socioeconomic life of its members and diverse communities where parishes are situated are in operation. RCCG, in different cities in Nigeria, undertakes charitable activities. Such initiatives include promotion of microfinance banks, youth camps, poverty alleviation initiatives, empowerment programmes, healthcare delivery to the less privileged and contributions to their communities through a wide range of social, spiritual and empowerment 
programmes as well as educational activities to minimise the effects of the nation's dysfunctional educational system. For instance, when the late President Musa Yar'Adua authorised the amnesty for militants of the Niger Delta on 25 June 2009, Redeemer's University, Ede, owned by the RCCG was actively involved in providing support, counselling, mentoring and resettlement of some members of the militant group into society.

Burgess $(2011,160)$, in his research on Nigerian Pentecostal Churches, argued that 'religion had re-emerged as a potent political force and dominant feature in the national and political culture'. On the international scene, on 21 June 2016:

the General Overseer of RCCG, Pastor Enoch Adeboye, paid a courtesy visit to the United Nations Secretary General, Mr Ban Ki-Moon, in order to explore opportunities provided in the UN system to leverage on the influence of the church and its leadership in facilitating interfaith harmony and peace, creating a conducive environment for action towards attainment of the Sustainable Development Goals (SDGs).

(OnoBello.com 2016)

Adeboye, in his meeting with Mr Ban Ki-Moon, also stated 'that the Redeemed Christian Church of God is focused on impacting the entire global community positively through the platform of its Christian faith and values'. It was emphasised that the church 'remains acutely aware of the need to go beyond business as usual to reach (and continue to engage) the youth population' (OnoBello.com 2016).

\section{Social capital}

The concept of social capital has been noted to be multifaceted as well as potentially ambiguous. The idea of social capital illustrates the significance and effects of social affability and 'connectedness and their relations to the individual and social structure' (Tzanakis 2013, 2). Social capital in different forms has come under the scrutiny of scholars like Durkheim, Marx, Weber and Tönnies as noted by Quibria (2003, 1). Coleman's (1988) and Putnam's (2000) 'definitions, each based on extensive empirical research, are among the most widely cited. A qualification added by [some] writers, including Putnam, is that the networks and norms are capable of being used for mutual or collective benefit' (Kilpatrick et al. 2003, 419). RCCG contributes significantly to community cohesion and development through the social capital of its members by being socially rooted and having shared values (Adedibu 2010, 199). Social capital has been identified by policymakers and politicians alike as a potential source of economic and social benefits due to its maximisation in civic engagement. Interestingly, RCCG parishes in Nigeria, through the shared vision of the denomination, have risen to the challenges within their host communities through their corporate social responsibility initiatives. The effectiveness of most social action is 
rooted in the in situ local knowledge of the church about its context in Nigeria as well as in the diaspora. RCCG provides elements of social capital through bonding, bridging and linking; it presents a formidable front to confront various factors that militate against development. The sacred spaces for worship in these churches do not only foster socialisation, rituals and religious practices, but also serve as social and business areas which provide bridge-building and linkbuilding among members. RCCG is thereby leading to a local and global flow of information and generation of interest and trust based on shared values.

I have previously observed that some scholars such as Bourdieu and Wacquant $(1992,119)$ have identified religious capital as part of social capital in faith-based organisations like RCCG and it 'is, therefore, the effects of religious and spiritual practices, beliefs, networks and institutions that have a measurable impact on individuals, communities, and societies'. Also, social capital refers to the various opportunities appropriated by a person such as influence, power and knowledge in a group. Likewise, spiritual capital has been appropriated by RCCG leadership largely through their authority, sway and dispositions in encouraging volunteering, philanthropy and social services. Significant numbers of volunteers are utilised during most programmes of the church, such as the Holy Ghost Congress. Volunteering enhances the bridging of social capital, creating links with people outside their immediate circles. Volunteering is an avenue for the development of 'a well-connected network that includes people from across a range of professions. Embedded in a well-connected network is workplace information which volunteers can use to help choose career paths, find work or find a new job' (Polidano et al. 2007, 4).

Asamoah-Gyadu $(2013,181)$ was quite succinct in his argument on the contributions of African Pentecostal Churches through human flourishing which he posited as the transformation of members of these faith communities into the likeness of Jesus Christ. The various testimonies of many adherents who were transformed as a result of their commitment to the Christian faith as well as its moral and religious codes inevitably leads to good citizenship and human development. At the RCCG 2016 Holy Ghost Congress, a young man, an undergraduate at one of the universities in the country, testified that he was a former cultist and engaged in occult practices but after he became born again, he was completely transformed. The impact of the aforementioned narrative is that apparent ethical personality is to be perceived by the civic community in respect of the born-again social life.

\section{RCCG as an agent of social transformation}

In light of the mission and vision statements of RCCG, its missionary ethos is evident. The religious creativity and innovations through the routinisation of charisma by Enoch Adeboye are synonymous with his aspiration to reach out to the unchurched. The multiplicities of programmes for virtually every social strata of society are reflective of the fact that RCCG is an agent of social transformation. Farinto $(2010,2)$ posits that: 


\section{Babatunde A. Adedibu}

the church in mission [as] an agent of change[s], indicates the spiritual impact of the presence of God in His creation. When a man first experiences the divine transformation of God, it is spiritual and physical, and then the human society, both the sacred and secular, feels its impact.

Farinto's assertion is not only prescriptive, but also revealing that the liturgical practices of RCCG, rituals and religious practices ultimately should produce citizens who intensely manifest purity and divine consciousness leading to reconciliation in relationships with God and men. The impact includes personal transformation and character development which is reflected in moral consciousness and good citizenship thereby leading to reduction of social ills as well as biblical standards as a yardstick for social, economic and public life. This is achieved through the evangelistic programmes like the Holy Ghost Services, Holy Ghost Congress, Campus Holy Ghost Service and Divine Encounter. The Campus Holy Ghost Services (CHGS) is the name given to the Holy Ghost Services that are conducted on the campuses of tertiary institutions in Nigeria. CHGS came into existence against the backdrop of increasing violence among campus gangs, popularly called campus secret cults (CSCs).

Ukah $(2003,231)$ noted that:

On 10 July, 1999, some students at the Obafemi Awolowo University (OAU), who professed to belong to a gang, murdered fellow students in cold blood. In one night, about seven students were killed and several injured. Following this event, students took laws into their hands, and in their uncontrolled attempts to extirpate CSCs from OAU, Ife-Ife, hunted down and killed some identified members of CSCs, increasing the number of those killed and adding to the flurry of lawlessness and violence. Before this period, CSCs' activities in different Nigerian universities had claimed the lives of no fewer than twenty-five students.... Consequently, Adeboye was consulted, mandated and mobilised by the [former] President of the Federal Republic of Nigeria, Olusegun Obasanjo, and some university administrators to help in the sanitisation of the social and moral life of students. According to the President Obasanjo as '[w] e were considering this problem (of students' cultism) and as I was looking for ways and means of dealing with it, I rubbed minds with Pastor Adeboye and he took the responsibility to go to the institutions of higher learning'.

RCCG provides a model for the contemporary Nigerian Church with respect to its holistic ministry approaches. Since its establishment, RCCG has 'engaged in missions as an agent of transformation in individuals, groups and corporate entities, in the sense of seeking positive change in the whole of human life, spiritually, materially and socially' (Agbiji 2012, 156). CHGS first took place at OAU, on 17 November, 1999. Ukah $(2003,231)$ stated that 
Two months after, it [CHGS] was hosted by the University of Ibadan on 14 January 2000; and the following month [sic] it was the turn of Lagos State University (LASU) to play host to the divine guest on 11 February 2001. The University of Ilorin, where Adeboye once taught, played host to the event on 11 October 2002.

The impact of this initiative has complemented various universities' stance on zero tolerance to student cultism as well as veritable opportunity for campus evangelism and recruitment of new members into the Redeemer's Christian Fellowship (RCF), which is the campus fellowship of RCCG.

\section{Responding to social and health challenges}

RCCG, over the years, has been actively involved in various social, health and educational initiatives to ameliorate not only the challenges of its members, but also complement existing healthcare delivery in Nigeria and the diaspora. Riding on the crest of holistic philosophy, RCCG is creatively involved in the rehabilitation of drug-ridden youth as well as resettlement initiatives for a broad range of women involved in sex trafficking repatriated from Europe to Nigeria. To present an integrated approach to human and community development, the denomination over the years has developed a network of collaborative partners through its transnational network of churches with faith-based organisations in the diaspora to address some of the cogent health challenges. RCCG established various para-church organisations to address these social and health concerns. In a previously published article (Akhazemea and Adedibu 2011), the author chronicled the contributions of RCCG to healthcare delivery in Nigeria which are explored in detail below.

One paramount concern in Nigeria, as in many other African countries, is the HIV/AIDS pandemic. Akhazemea and Adedibu $(2011,58)$ noted that RCCG's perspective on HIV/AIDS is receptive of medical approaches embraced preventative approaches to curb the spread of HIV/AIDS. This is antithetical to Tiendrebeogo and Buykx's (2005, 15-16), who argued that:

HIV/AIDS juxtapose the interwoven issues of religious doctrines, ethics, morality and the official positions of religious hierarchies' perspectives.... In many countries, HIV/AIDS strategies, such as condom promotion, faced tremendous obstacles from faith-based organizations.... Religious leaders often reach a deadlock with other stakeholders over condom use and mandatory testing before marriage. They may also have contributed to selfstigmatization which is common among followers who find themselves HIV positive.

Akhazemea and Adedibu $(2011,58)$ succinctly capture the positive appropriation of medical science as well as religious capital in ameliorating the challenges of Nigerians infected with HIV/AIDS and creating awareness of the 
associated health risks and social stigma of infection with HIV/AIDS. According to Adogame (2007), the Redeemed AIDS Programme Action Committee (RAPAC) is the para-church ministry of RCCG responsible for using multiple approaches including education, production of behavioural communication resources on HIV/AIDS, advocacy of moral restraint, creating awareness and offering medical assistants to members of the church and the larger communities. Due to the transnational status of RCCG, RAPAC collaborates with various non-governmental organisations and multilateral agencies across borders to meet its founding objectives. For instance, Akhazemea and Adedibu (2011, 58) noted that

RAPAC initiatives were given impetus in 2005 with the selection of the organisation as one of the agencies in Nigeria to implement the HIV/ Counselling and Testing (HCT) project as part of the Global HIV/AIDS (GHAIN) initiative in Lagos state, with the support of the United States Agency for International Development (USAID)/Family Health International.

\section{Campaign against Drug Abuse Ministry}

Substance abuse and its associated challenges is fast becoming a major social ill across the globe, Nigeria inclusive. Campaign against Drug Abuse Ministry (CADAM) is the social arm of the RCCG charged with addressing the challenge of substance abuse within and outside the church providing succour to those who are involved in the abuse of substances. Akhazemea and Adedibu $(2011,61)$ noted that, 'CADAM is a well-structured unit of the church that recognises the holistic care delivery to drug addicts and ex-drug addicts. The understanding is reflective of their integrative approach to the delivery of health and spiritual care to drug users.' CADAM makes use of holistic healthcare delivery for her clients including medical and religious approaches with varying level of success over the years. At the dedication of its new facilities on 4 October 2017, the then Lagos State Governor, Mr Akinwunmi Ambode stated that:

CADAM has, on its own, with it[s] own resources, picked up, fed, sheltered, treated and rehabilitated many people who have been addicted to drugs, and given them a new life. I am optimistic that many lives that had been compromised as a result of drug addiction will be redeemed, stabilised and given a new hope for a better and meaningful future.

(Flashnews.com.ng 2017)

Since its inception, CADAM has 'treated about 2000 people with $70 \%$ of them living drug free, independent and productive lives in various professions' (Folu Adeboye, quoted in Odesola 2017, 15). The case of Ilimezekhe Salvage, who was rehabilitated from substance abuse and eventually graduated from university 
(Adeboye 2007a, 37; Odesola 2017, 16) says much about what the denomination is doing through CADAM. Some of the rehabilitated drug users are well integrated into society and gainfully employed. For instance, Victor Edo, a former drug peddler stated that

I sold my blood just to satisfy my urge ... I was the kingpin of Ikeja Cocaine Triangle. The media beamed its search light aggressively on us in 1987. The NDLEA [National Drug Law Enforcement Agency] eventually arrested me. My father and my relatives rejected me, but eventually I came to CADAM in 1998. Here I was healed. And today, I am an ordained Pastor.

(CSR Chronicles 2018, 13)

\section{RCCG educational approaches to development}

In the last three decades RCCG has succeeded in redefining herself as a forwardlooking and educationally minded church. The flourishing school movement of RCCG started from a humble beginning at Ebute Meta in 1981, where Folu and Enoch Adeboye pioneered the first primary school. This led to the formation of Christ Redeemers School Movement (CRSM) which is part of the Children and Teens Department of the RCCG under the leadership of Folu Adeboye as director and chairperson. The commencement of RCCG's educational agenda has been linked with the vision of Enoch Adeboye of looking forward to a future when an education including distinctive Christian philosophy from elementary education to tertiary institutions would be a reality. The first secondary school established by the CRSM was Christ Redeemer College, Sagamu, Ogun State which was dedicated on 1 October 1996. CRSM has registered its presence in almost all the communities where RCCG parishes are situated. In furtherance of the founding ideals of the school movement of RCCG, the denomination's university known as the Redeemer's University, Ede (RUN) which took off in 2005. In 2018, RCCGestablished Redeemer's College of Technology and Management was approved by the Nigeria's National Board for Technical Education. Apart from these institutions, RCCG established its foremost theological college, the Redeemed Christian Bible College in 1980 which is now an affiliate of the department of Christian Religious Studies, University of Ibadan, and Redeemer's University, Ede. The institution is saddled with the responsibility of training the ministerial manpower needs of RCCG. These institutions established by RCCG contribute significantly to human capacity and national development.

\section{Conclusion}

In this chapter, I have demonstrated the nexus between religion and development. The evolving new concepts of human and sustainable developments give the opportunity to re-examine the lived religious experiences using the RCCG, Nigeria, as a point of reference. RCCG makes use of a multifaceted approach which includes the use of socio and religious capital and the appropriation of the 
public space for various socioeconomic and community development initiatives. The use of a case study has enabled this work to explain the nexus between religion and development through a descriptive approach, by observation, and through an analysis of the contributions of RCCG to development in Nigeria.

\section{Note}

1 The following paragraphs largely follow the author's review of Gifford's (2016) book in African Studies Quarterly (Adedibu 2017).

\section{References}

Adeboye, Olofunke. 2005. 'Pentecostal Challenges in Africa, and Latin America: A Comparative Focus on Nigeria and Brazil.' Afrika Zamani 11 and 12 (2003/2004): 136-159.

Adeboye, Olofunke. 2007a. Dispensing Spiritual Capital: Faith-Based Response to the HIV/ AIDS Epidemic in Nigeria. Lagos: University of Lagos, Faculty of Arts.

Adeboye, Olofunke. 2007b. "“Arrowhead” of Nigerian Pentecostalism: The Redeemed Christian Church of God, 1952-2005.' Pneuma 29, no. 1: 24-58.

Adedibu, Babatunde. 2010. 'The Urban Explosion of Black Majority Churches: Their Origin, Growth, Distinctives and Contribution to British Christianity.' Doctoral thesis, North-West University, Potchefstroom.

Adedibu, Babatunde. 2016. 'Redemption Camp, Mowe, Ogun State, Nigeria: A Sacred Space of Religious Innovations and Creativity.' Journal of Religion and African Culture 4, no. 1: 6-21.

Adedibu, Babatunde. 2017. 'Paul Gifford. 2016. Christianity, Development, and Modernity in Africa. New York: Oxford University Press. 187 pp'. Book review. African Studies Quarterly 17, no. 2: 94-95.

Adedibu, Babatunde. 2018. 'The Changing Faces of African Independent Churches as Development Actors Across Borders.' HTS Teologiese Studies/Theological Studies 74, no. 1. https://doi.org/10.4102/hts.v74i1.4740.

Adogame, Afe. 2007. 'HIV/AIDS Support and African Pentecostalism: The Case of the Redeemed Christian Church of God (RCCG).' Journal of Health Psychology 12, no. 3: 475-484.

Adogame, Afe. 2013. 'Reconfiguring the Global Religious Economy: The Role of African Pentecostalism.' In Spirit and Power: The Growth and Global Impact of Pentecostalism, edited by Donald E. Miller, Kimon H. Sargeant, and Richard Flory. Oxford: Oxford University Press.

Adogame, Afe. 2016. 'African Christianities and the Politics of Development from Below.' HTS Teologiese Studies/Theological Studies 72, no. 4.

Agbiji, Obaji Mbeh. 2012. 'Development-Oriented Church Leadership in Postmilitary Nigeria: A Sustainable Transformational Approach.' Doctoral dissertation, Stellenbosch University.

Akhazemea, Daniel, and Babatunde Adedibu. 2011. 'Global Missionary Player: The Redeemed Christian Church of God: Her Message of Human Development.' In Encounter Beyond Routine. Cultural Roots, Cultural Transition, Understanding of Faith and Cooperation in Development, edited by EMW (Evangelisches Missionswerk in Deutschland e.V.), 53-64. Hamburg: EMW. 
Asamoah-Gyadu, Kwabena. 2013. Contemporary Pentecostal Christianity, Interpretations from an African Context. Eugene, OR: Wipf and Stock Publishers.

Belshaw, Deryke, Robert Calderisi, and Chris Sugden, eds. 2001. Faith in Development: Partnership between the World Bank and the Churches of Africa. Washington, DC: World Bank and Oxford: Regnum Books International.

Bolarinwa, J. 2005. The Redeemed Christian Church of God: Beliefs and Practices. Lagos: Somerset Ventures.

Bompani, Barbara. 2012. 'Religion and Development from Below: Independent Christianity in South Africa.' Journal of Religion in Africa 40, no. 3: 307-330. http://dx.doi. org/10. 1163/157006610X525435.

Bourdieu, Pierre, and Loïc J. D. Wacquant. 1992. An Invitation to Reflective Sociology. Chicago: University of Chicago Press.

Burgess, Richard, Kim Knibbe, and Anna Quaas. 2010. 'Nigerian-Initiated Pentecostal Churches as a Social Force in Europe: The Case of the Redeemed Christian Church of God.' PentecoStudies 9, no. 1.

Burgess, Richard. 2011. 'Practical Christianity and Public Faith: Nigerian Pentecostal Contributions to Intercultural Theology.' In Intercultural Theology: Approaches and Themes, edited by Mark J. Cartledge, and David Cheetham. London: SCM Press.

Clark, Helen. 2015. 'Foreword' in: Human Development Report 2015. Work for Human Development. New York: United Nations Development Programme, iii-iv.

Commission for Africa. 2005. Our Common Interest: Report of the Commission for Africa. London: Penguin Books.

Coleman, James S. 1988. 'Social Capital in the Creation of Human Capital.' American Journal of Sociology 94: 95-120.

Crabtree, Steve. 2010. 'Religiosity Highest in World's Poorest Nations.' 31 August 2010. https://news.gallup.com/poll/142727/religiosity-highest-world-poorest-nations.aspx.

CSR Chronicles, The. 2018. The CSR Chronicles, August 2018. Lagos: Redeemed Christian Church of God.

Deneulin, Séverine, and Carole Rakodi. 2010. 'Revisiting Religion: Development Studies Thirty Years on.' World Development 39, no. 1: 45-54.

Ellis, Stephen, and Gerrie Ter Haar. 2004. Worlds of Power. Religious Thought and Political Practice in Africa. London: Hurst.

Farinto, A. O. 2010. 'Church in Mission: An Agent for Transformation.' Paper presented at the National Conference for Christian Leaders, Christian Association of Nigeria, Abuja.

Flashnews.com.ng. 2017. 'RCCG Opens Drug Abuse Rehabilitation Centre'. 4 October 2017. www.flashnews.com.ng/2017/10/04/rccg-opens-drug-abuse-rehabilitation-centre/.

Freeman, Dena, ed. 2012. Pentecostalism and Development: Churches, NGOs and Social Change in Africa. London: Palgrave Macmillan.

Frost, Marie-Luise, Philipp Öhlmann, and Wilhelm Gräb. 2018. 'Avoiding "White Elephants" - Fruitful Development Cooperation from the Perspective of African Initiated Churches in South Africa and Beyond.' In The Changing Faces of African Pentecostalism, edited by Babatunde Adedibu, and Benson Igboin, 103-118. Akungba-Akoko: Adekunle Ajasin University Press.

Gifford, Paul. 1998. African Christianity: Its Public Role. London: Hurst \& Co.

Gifford, Paul. 2016. Christianity, Development, and Modernity in Africa. New York: Oxford University Press.

Kilpatrick, Sue, John Field, and Ian Falk. 2003. 'Social Capital: An Analytical Tool for Exploring Lifelong Learning and Community Development.' British Educational Research Journal 29, no. 3: 417-432. 
Marshall, Katherine, and Lucy Keough. 2004. Mind, Heart, and Soul in the Fight Against Poverty. Washington, DC: World Bank.

Miller, Donald E., and Tetsunao Yamamori. 2007. Global Pentecostalism, The New Face of Christian Social Engagement. Berkeley: University of California Press.

Odesola, Johnson, ed. 2017. The Good Samaritan 1 (8). Lagos: Redeemed Christian Church of God, Lagos.

Offutt, Stephen, LiErin Probasco, and Brandon Vaidyanathan. 2016. 'Religion, Poverty and Development.' Journal for the Scientific Study of Religion 55, no. 2: 207-215. http:// dx.doi.org/10. 1111/jssr.12270.

Öhlmann, Philipp, Marie-Luise Frost, and Wilhelm Gräb. 2016. 'African Initiated Churches' potential as development actors.' HTS Teologiese Studies/Theological Studies 72, no. 4. a3825. http://dx.doi.org/10.4102/hts.v72i4.3825.

OnoBello.com. 2016. 'Pastor Enoch Adeboye Meets with UN Secretary General, Ban Ki-Moon.' 22 June, 2016. http://onobello.com/pastor-enoch-adeboye-meets-with-unsecretary-general-ban-ki-moon/.

Polidano, Cain, Mark Harris, and Xueyan Zhao. 2019. 'Volunteering for Work and Pleasure?' Department of Econometrics and Business Statistics, Monash University. https://melbourneinstitute.unimelb.edu.au/assets/documents/hilda-bibliography/ conference-papers-lectures/2007/Polidano_ESAM.pdf.

Probasco, LiErin. 2016. 'Prayer, Patronage, and Personal Agency in Nicaraguan Accounts of Receiving International Aid.' Journal for the Scientific Study of Religion 55, no. 2: 233-249. http://dx.doi.org/10.1111/jssr.12263.

Putnam, Robert D. 2000. Bowling Alone: The Collapse and Revival of American Community. New York: Simon \& Schuster.

Quibria, M.G. 2003. 'The Puzzle of Social Capital: A Critical Review.' ERD Working Paper no. 40, Asian Development Bank.

Schnable, Allison. 2016. 'What Religion Affords Grassroots NGOs: Frames, Networks, Modes of Action.' Journal for the Scientific Study of Religion 55, no. 2: 216-232. http:// dx.doi. org/10.1111/jssr.12272.

Tarimo, Aquiline. 2005. Applied Ethics and Africa's Social Reconstruction. Nairobi: Acton Publishers.

Tiendrebeogo, G., and M. Buykx. 2005. Faith-Based Organisations and HIV/AIDS Prevention and Impact Mitigation in Africa. Amsterdam: KIT Publishers.

Tzanakis, Michael. 2013. 'Social Capital in Bourdieu's, Coleman's and Putnam's Theory: Empirical Evidence and Emergent Measurement Issues.' Educate 13, no. 2: 2-23.

Ukah, Asonzeh. 2003. 'The Redeemed Christian Church of God (RCCG), Nigeria. Local Identities and Global Processes in African Pentecostalism.' Doctoral dissertation, Universität Bayreuth.

Ukah, Asonzeh. 2008. A New Paradigm of Pentecostal Power: A Study of the Redeemed Christian Church of God. New Jersey: Africa World Press. 